\title{
Increased fetal leptin in Type I diabetes mellitus pregnancies complicated by chronic hypoxia
}

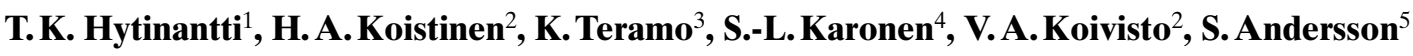 \\ ${ }^{1}$ Helsinki City Maternity Hospital, Helsinki University Central Hospital, Helsinki, Finland \\ ${ }^{2}$ Department of Medicine, Helsinki University Central Hospital, Helsinki, Finland \\ ${ }^{3}$ Department of Obstetrics and Gynecology, Helsinki University Central Hospital, Helsinki, Finland \\ ${ }^{4}$ Department of Clinical Chemistry, Helsinki University Central Hospital, Helsinki, Finland \\ ${ }^{5}$ Hospital for Children and Adolescents, Helsinki University Central Hospital, Helsinki, Finland
}

\section{Abstract}

Aims/hypothesis. The purpose of this study was to examine whether fetal leptin concentration correlates with severity of chronic or subchronic fetal hypoxia as indicated by increased fetal concentrations of erythropoietin in fetuses of mothers with Type I (insulin dependent) diabetes mellitus.

Methods. We measured leptin and erythropoietin concentrations in cord plasma and amniotic fluid with radioimmunoassay in 25 pregnancies (gestational age $37.2 \pm 1.0$ weeks). Fetuses with amniotic fluid erythropoietin over $22.5 \mathrm{mU} / \mathrm{ml}$ were classified as hypoxic $(n=9)$ and those with amniotic fluid erythropoietin below $22.5 \mathrm{mU} / \mathrm{ml}(n=16)$ as non-hypoxic.

Results. The hypoxic fetuses had significantly higher cord leptin concentrations than non-hypoxic fetuses (median 36.8; range, 12.5-135.1 vs median 16.2; range, $3.7-52.2 \mu \mathrm{g} / \mathrm{l}),(p=0.0066)$. Cord plasma leptin $(n=25)$ correlated directly with amniotic fluid erythropoietin $(r=0.727, p=0.0001)$, with cord plasma erythropoietin $(r=0.644, p=0.0005)$ and with the maternal last trimester $\mathrm{HbA}_{1 \mathrm{C}}(r=0.612, p=0.0019)$ and negatively with cord artery $\mathrm{pO}_{2}(r=-0.440$, $p=0.032)$, and $\mathrm{pH}(r=-0.414, p=0.040)$.

Conclusion/interpretation. Fetal leptin concentrations increased concomitantly with erythropoietin during chronic or subchronic hypoxia. This phenomenon could indicate a role for leptin in fetal adaptation to hypoxia. [Diabetologia (2000) 43: 709-713]

Keywords Leptin, erythropoietin, hypoxia, fetus, diabetes mellitus.
Leptin is an adipocyte-derived hormone involved in energy metabolism and fuel homeostasis [1-3]. It could also be important in fetal development because both the leptin gene and leptin receptors are expressed in numerous fetal tissues $[4,5]$. In addition, leptin has been shown to stimulate fetal erythroid development and to have angiogenic activity $[6,7]$.

In term infants, cord blood leptin concentrations correlate directly with birth weight [8-11]. Maternal diabetes mellitus and pre-eclampsia are also associated with increased cord blood leptin concentrations

Received: 20 December 1999 and in final revised form: 15 March 2000

Corresponding author: T. Hytinantti, MD, Helsinki City Maternity Hospital, Sofianlehdonkatu 5, 00610 Helsinki, Finland Abbreviations: EPO, Erythropoietin.
[12-14]. It has been postulated that hypoxic conditions during pre-eclampsia augment placental production of leptin [14].

Erythropoietin (EPO), which regulates the synthesis of bone marrow progenitor cells and erythrocytes [15], is produced in the fetal liver and near term also in the kidney [15]. The main stimulator of EPO production is tissue hypoxia $[15,16]$. Erythropoietin has also been shown to be produced by placental trophoblast cells. Whether EPO expression in placenta is regulated by hypoxia and the proportion of placental EPO of all EPO in feto-placental circulation is not known [17]. Because EPO is not stored, plasma EPO concentrations are an indicator of the rate of EPO synthesis. Fetal plasma EPO concentrations correlate well with those of amniotic fluid EPO before labour both in normal and in abnormal pregnancies [18]. In response to moderate to severe tissue hypoxia, a sta- 
Table 1. Patient data of the infants

\begin{tabular}{lll}
\hline & Mean (SD) & Range \\
\hline Males/Females $(n)$ & $14 / 11$ & \\
Gestational age (weeks) & $37.2(1.0)$ & $35.3-39.3$ \\
Birth weight (g) & $3962(762)$ & $2690-5430$ \\
Relative birth weight (SD) & $2.0(1.8)$ & $-1.1-5.6$ \\
Length $(\mathrm{cm})$ & $49.6(2.6)$ & $44.5-53.5$ \\
BMI $\left(\mathrm{kg} / \mathrm{m}^{2}\right)$ & $15.9(1.9)$ & $12.2-19.7$ \\
Head circumference $(\mathrm{cm})$ & $35.1(1.5)$ & $31.5-38.0$ \\
Apgar score & $9(1)$ & $7-10$ \\
Cord artery $\mathrm{Hb}(\mathrm{g} / \mathrm{l})$ & $154(16)$ & $120-183$ \\
Cord artery $\mathrm{pO} 2(\mathrm{kPa})$ & $2.2(0.4)$ & $1.1-2.9$ \\
Cord artery $\mathrm{pH}$ & $7.24(0.05)$ & $7.15-7.35$ \\
\hline
\end{tabular}

tistically significant increase in plasma EPO concentrations can be measured within 2 to $4 \mathrm{~h}$ [16]. Increased fetal plasma and amniotic fluid EPO concentrations have been observed in pregnancies complicated by pre-eclampsia, intrauterine growth restriction, and maternal diabetes $[18,19]$.

Fetal hypoxia is a frequently encountered complication in diabetic pregnancies [18]. Previous data indicate that the production of leptin is increased during hypoxia and EPO is a well-documented marker of fetal hypoxia. We therefore examined whether any association exists between the severity of fetal hypoxia, as indicated by fetal EPO concentrations and the concentration of leptin in cord blood at birth.

\section{Subjects and methods}

Subjects. We measured leptin and erythropoietin concentrations in cord vein plasma and in amniotic fluid samples from 25 singleton fetuses of mothers with Type I (insulin-dependent) diabetes mellitus. Of the mothers seven, in addition, had pre-eclampsia. These mothers' glycaemic control was evaluated by the glycated haemoglobin- $A_{1 C}$ fraction $\left(\mathrm{HbA}_{1 \mathrm{C}}\right)$ every 2 to 4 weeks throughout pregnancy. During the last month, their mean $\mathrm{HbA}_{1 \mathrm{C}}$ (SD) was $6.8 \%(1.2 \%)$, (range, $4.6-9.8 \%$ ). All infants in this study were delivered by elective caesarean section, the indications for which were complicated maternal diabetes, contracted pelvis, previous caesarean section or fetal macrosomia. Amniotic fluid samples were obtained by amniocentesis done within 3 days before the operation for measuring fetal lung maturity or at caesarean section.

Gestational age, corrected by ultrasound examination, ranged from 35.3 to 39.3 weeks and birth weight from 2690 to $5430 \mathrm{~g}$. The relative birth weight, as calculated by reference to a series of 74766 Finnish singleton newborns, ranged from -1.1 to $5.6 \mathrm{SD}$ (Table 1 ). Of the infants 11 were large for their gestational age: relative birth weight greater than $2.0 \mathrm{SD}$. In normal, term singelton pregnancies $(n=17)$ we have previously found a median amniotic fluid EPO of $7.5 \mathrm{mU} / \mathrm{ml}$, (range, $4.2-19.1 \mathrm{mU} / \mathrm{ml}$ ) [18], which is almost identical to that reported by others [20]. We considered three times the median amniotic fluid EPO $(22.5 \mathrm{mU} / \mathrm{ml})$ to be the limit of fetal hypoxia (Table 2).

The study was approved by the ethics committee of the Department of Obstetrics and Gynaecology of the Helsinki University Central Hospital.
Table 2. Data on hypoxic (amniotic fluid EPO $>22.5 \mathrm{mU} / \mathrm{ml}$ ) and non-hypoxic (amniotic fluid EPO $\leq 22.5 \mathrm{mU} / \mathrm{ml}$ ) infants

\begin{tabular}{|c|c|c|}
\hline & $\begin{array}{l}\text { Hypoxic } \\
\text { infants }(n=9) \\
\text { mean }(\mathrm{SD})\end{array}$ & $\begin{array}{l}\text { Non-hypoxic } \\
\text { infants }(n=16) \\
\text { mean }(\mathrm{SD})\end{array}$ \\
\hline Gestational age (weeks) & $36.5(0.8)$ & $37.6(1.0)^{\mathrm{a}}$ \\
\hline Birth weight $(\mathrm{g})$ & 3917 (797) & $3987(766)$ \\
\hline Relative birth weight (SD) & $2.5(2.0)$ & $1.7(1.7)$ \\
\hline Length $(\mathrm{cm})$ & $49.1(2.7)$ & $50.0(2.6)$ \\
\hline $\mathrm{BMI}\left(\mathrm{kg} / \mathrm{m}^{2}\right)$ & $16.1(2.2)$ & $15.9(1.9)$ \\
\hline Head circumference $(\mathrm{cm})$ & $34.5(1.5)$ & $35.5(1.5)$ \\
\hline Apgar score & $9(0)$ & $9(1)$ \\
\hline Maternal pre-eclampsia ( $n$ ) & 3 & 4 \\
\hline Maternal $\mathrm{HbA}_{1 \mathrm{C}}(\%)$ & $7.4(1.2)$ & $6.5(1.1)$ \\
\hline Cord artery $\mathrm{pO}_{2}(\mathrm{kPa})$ & $1.9(0.5)$ & $2.3(0.3)^{\mathrm{a}}$ \\
\hline Cord artery $\mathrm{Hb}(\mathrm{g} / \mathrm{l})$ & $157(13)$ & $158(12)$ \\
\hline Cord artery $\mathrm{pH}$ & $7.21(0.06)$ & $7.25(0.04)$ \\
\hline
\end{tabular}

${ }^{\mathrm{a}} p<0.05$, hypoxic vs non-hypoxic infants

Methods. Blood samples obtained from the cord vein were drawn at birth into EDTA tubes, which were centrifuged at $1000 \times g$ for $5 \mathrm{~min}$ and the plasma stored at $-20^{\circ} \mathrm{C}$ until analysis. Amniotic fluid samples were drawn into EDTA tubes and stored at $-20^{\circ} \mathrm{C}$. Leptin and EPO were measured by radioimmunoassay (Linco Research, St Charles, Mo., USA; and EPO-Trac, Incstar, Stillwater, Minn, USA, respectively) [21, 22].

Statistical analysis. Leptin and EPO concentrations were logarithmically transformed to normalise distribution when appropriate. Simple and multiple regression analyses were used. Patient data are given as mean, SD and range, and results as median and range or quartiles. Comparison between groups was done with the Mann-Whitney $\mathrm{U}$ test. A value of $p$ less than 0.05 was considered statistically significant. All calculations were done with StatView 4.1 (Abacus Concepts, Berkeley, Calif., USA).

\section{Results}

Cord plasma median concentration of leptin was $9.0 \mu \mathrm{g} / \mathrm{l}$ (range, 3.7-135.1 $\mu \mathrm{g} / \mathrm{l}$ ) and that of EPO $26.2 \mathrm{mU} / \mathrm{ml}$ (range, $9.6-9263 \mathrm{mU} / \mathrm{ml}$ ). In amniotic fluid, median concentration of leptin was $2.2 \mu \mathrm{g} / \mathrm{l}$ (range, $0.7-5.7 \mu \mathrm{g} / \mathrm{l}$ ) and that of EPO $10.9 \mathrm{mU} / \mathrm{ml}$ (range, $1.0-1594 \mathrm{mU} / \mathrm{ml}$ ).

The fetuses of the hypoxic group had higher cord leptin concentrations (median 36.8; range, 12.5-135.1 $\mu \mathrm{g} / \mathrm{l})$ than those in the non-hypoxic group (median 16.2; range, 3.7-52.2 $\mu \mathrm{g} / \mathrm{l}$ ), $\quad p=0.0066$ (Fig.1). Fetuses of the hypoxic group had lower gestational age $(p=0.016)$ and cord artery $\mathrm{pO}_{2}(p=$ 0.023 ) at birth (Table 2). Between groups, maternal $\mathrm{HbA}_{1 \mathrm{C}}(p=0.1), \mathrm{Hb}(p=0.5)$, and base excess (BE) $(p=0.2)$ did not differ significantly, although cord blood $\mathrm{pH}$ was close to statistically significant difference $(p=0.06)$.

In all fetuses, significant correlation existed between cord plasma leptin and amniotic fluid EPO $(r=0.727, p=0.0001)$, cord plasma EPO $(r=0.644$, 
$p=0.0005$, Fig. 1$)$, maternal $\mathrm{HbA}_{1 \mathrm{C}} \quad(r=0.612$, $p=0.0019)$ and relative birth weight $(r=0.399$, $p=0.049)$; whereas negative correlations were found with cord artery $\mathrm{pO}_{2}(r=-0.440, p=0.032)$ and $\mathrm{pH}$ $(r=-0.414, p=0.040)$. In addition, significant correlations existed between amniotic fluid EPO and cord plasma EPO $(r=0.863, p=0.0001)$, maternal $\mathrm{HbA}_{1 \mathrm{C}}$ $(r=0.646, p=0.0009)$, cord artery $\mathrm{pO}_{2}(r=-0.644$. $p=0.0007)$ and $\mathrm{pH}(r=-0.558, p=0.0038)$. Neither cord plasma leptin, EPO nor amniotic fluid EPO correlated with cord haemoglobin concentration at birth. Nor did amniotic fluid leptin correlate with clinical data or with these biochemical variables.

In multiple regression analysis with cord plasma leptin as the dependent variable and amniotic fluid EPO, cord artery $\mathrm{pO}_{2}$, relative birth weight, maternal $\mathrm{HbA}_{1 \mathrm{C}}$ and gestational age as independent variables, only EPO (partial $r=0.558, p=0.031$ ) remained significantly associated with cord plasma leptin.

\section{Discussion}

Our study of these diabetic pregnancies shows that fetuses exposed to hypoxic conditions, as indicated by increased amniotic fluid EPO concentrations, have significantly higher cord plasma leptin concentrations. Moreover, in all fetuses, cord plasma leptin concentration strongly correlated with amniotic fluid and cord plasma EPO concentrations.

Our data are in agreement with the findings of another study [14] which showed that hypoxia increases placental leptin production. That study found that in vitro a rise in leptin production in placental cells did not take place until after $72 \mathrm{~h}$ of hypoxia [14]. Because during hypoxic conditions a significant increase in fetal EPO concentrations can be observed within 2 to $4 \mathrm{~h}$ [16], the increased cord plasma leptin, together with the increased EPO concentrations in both amniotic fluid and cord plasma, probably reflect chronic or subchronic rather than acute fetoplacental hypoxia.

We did not find a correlation between amniotic fluid or cord plasma EPO and cord haemoglobin. This is in accordance with previous studies of infants of diabetic mothers $[18,23]$, whereas a negative correlation has been reported between EPO and $\mathrm{Hb}$ in normal and Rh-isoimmunised fetuses [24]. There is evidence that in infants of diabetic mothers erythropoiesis is qualitatively abnormal [25]. Also, the response of erythropoiesis to EPO is different in the fetus and in the preterm infant than in the adult $[24,26]$. These observations could also partly explain the lack of correlation between cord leptin and haemoglobin.

Both maternal glycaemic control in diabetic pregnancies and pre-eclampsia affect cord plasma leptin concentrations $[13,14]$ and amniotic fluid and cord plasma EPO concentrations are also increased in such pregnancies $[18,19,20]$. Neither the number of
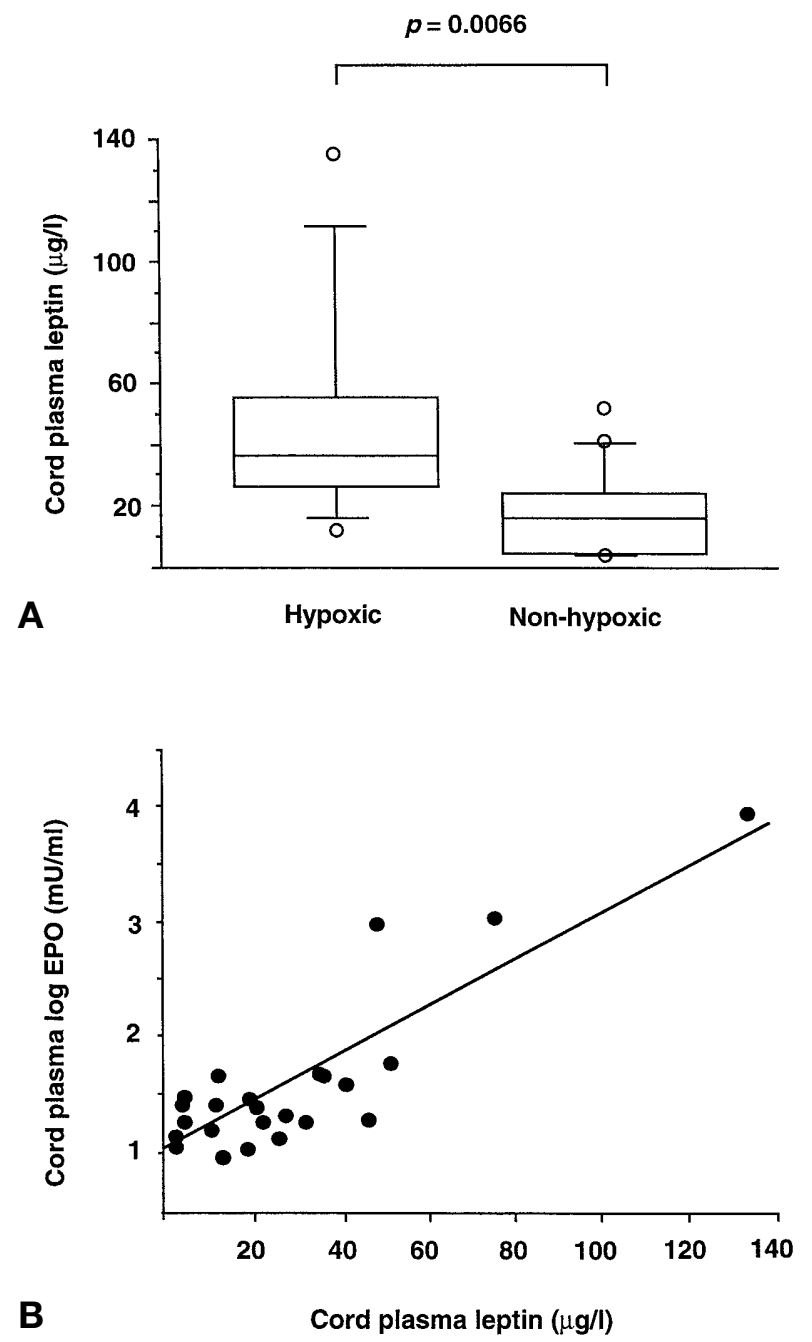

Fig. 1. A Box and whisker plot of cord plasma leptin concentrations of hypoxic $(n=9)$ and non-hypoxic $(n=16)$ fetuses at birth. B Correlation between umbilical cord EPO(log) and leptin

pre-eclamptic mothers nor the maternal $\mathrm{HbA}_{1 \mathrm{C}}$ significantly differed, however, between the hypoxic and non-hypoxic group of infants. In addition, all infants of this study were delivered by elective caesarean section, thus eliminating the possible hypoxia and increase in EPO concentration caused by labour [27]. Although a correlation existed between cord plasma leptin and cord blood $\mathrm{pH}$ and $\mathrm{pO}_{2}$, in multiple regression analysis only cord plasma EPO remained an independent and significant determinant of cord plasma leptin concentrations. We therefore feel that this difference between the groups in cord plasma leptin concentrations is primarily a result of fetal chronic or subchronic hypoxia.

Leptin has been shown to be involved in angiogenesis and to stimulate the proliferation of myelocytic and primitive haematopoietic progenitor cells $[7$, 28]. In vitro data indicate that leptin acts synergistically with EPO to increase fetal erythroid develop- 
ment [6]. Therefore, along with concomitantly increased EPO concentrations, increased leptin concentrations could represent a cooperative and physiologically feasible adaptation mechanism to improve oxygen transportation capability during periods of decreased oxygen supply. These beneficial effects of increased leptin concentration in the fetus might not be limited to stimulation of erythroid development and angiogenesis: the cytokine-like properties of leptin receptors and the better survival of adult septic patients with higher leptin concentrations has led to leptin being considered a stress-related hormone $[6$, $7,29,30]$. Leptin thus could improve fetal adaptation to stress such as chronic hypoxia.

We found a positive correlation between cord plasma leptin concentration and maternal $\mathrm{HbA}_{1 \mathrm{C}}$. This result suggests that maternal glucose metabolism affects leptin metabolism of the fetoplacental unit. This is supported by data showing that insulin increases leptin mRNA [31] and data indicating that leptin secretion in adipocytes is regulated by glucose metabolism [32]. An increase in leptin secretion from adipocytes has been shown to be primarily dependent on glucose, with the effect of insulin being secondary [32]. In diabetic mothers, the expression of leptin mRNA and protein in placental tissue is increased [33]. Thus, the correlation between cord plasma leptin and maternal $\mathrm{HbA}_{1 \mathrm{C}}$ could be an indicator of augmented leptin production in fetal adipocytes and in placenta.

Human amniotic fluid cells have been shown to secrete leptin into the amniotic fluid [34]. In our study, amniotic fluid leptin concentrations failed to correlate with any of the clinical or biochemical variables suggesting that secretion of leptin into the amniotic fluid is independent of these variables.

Our study indicates that in Type I diabetes pregnancies, cord plasma leptin concentration correlates with severity of fetal hypoxia, as indicated by the concentration of erythropoietin. This phenomenon could reflect a physiological response of the fetoplacental unit to chronic hypoxia.

Acknowledgements. This study was supported by grants from Finska Läkaresällskapet and the Foundation for Paediatric Research, Helsinki, Finland. We thank H. Puttonen, RN, for her valuable assistance in collecting the samples and C. Norris, $\mathrm{PhD}$, for linguistic revision of the manuscript.

\section{References}

1. Zhang Y, Proenca R, Maffei M, Barone M, Leopold L, Friedman JM (1994) Positional cloning of the mouse obese gene and its human homologue. Nature 372: 425-432

2. Pelleymounter MA, Cullen MJ, Baker MB et al. (1995) Effects of the obese gene product on body weight regulation in ob/ob mice. Science 269: 540-543

3. Rosenbaum M, Nicolson M, Hirsch J, Murphy E, Chu F, Leibel RL (1997) Effects of weight change on plasma leptin concentrations and energy expenditure. J Clin Endocrinol Metab 82: 3647-3654

4. Hoggard N, Hunter L, Duncan JS, Williams LM, Trayhurn P, Mercer JG (1997) Leptin and leptin receptor mRNA and protein expression in the murine fetus and placenta. Proc Natl Acad Sci USA 94: 11073-11078

5. Cioffi JA, Shafer AW, Zupancic TJ et al. (1996) Novel B219/OB receptor isoforms: possible role of leptin in hematopoiesis and reproduction. Nat Med 2: 585-588

6. Mikhail AA, Beck EX, Shafer A et al. (1997) Leptin stimulates fetal and adult erythroid and myeloid developent. Blood 89: 1507-1512

7. Sierra-Honigmann MR, Nath AK, Murakami C et al. (1998) Biological action of leptin as an angiogenic factor. Science 281: 1683-1686

8. Sivan E, Lin WM, Homko CJ, Reece EA, Boden G (1997) Leptin is present in human cord blood. Diabetes 46: 917-919

9. Hassink SG, de Lancey E, Sheslow DV et al. (1997) Placental leptin: An important new growth factor in intrauterine and neonatal development? Pediatrics 100: E11-E16

10. Schubring C, Kiess W, Englaro P et al. (1997) Levels of leptin in maternal serum, amniotic fluid and arterial and venous cord blood: relation to neonatal and placental weight. J Clin Endocrinol Metab 82: 1480-1483

11. Koistinen HA, Koivisto VA, Andersson S et al. (1997) Leptin concentration in cord blood correlates with intrauterine growth. J Clin Endocrinol Metab 82: 3328-3330

12. Persson B, Westgren M, Celsi G, Nord E, Ortqvist E (1999) Leptin concentrations in cord blood in normal newborns infants and offspring of diabetic mothers. Horm Metab Res 31: 467-471

13. Shekhawat PS, Garland JS, Shivpuri C et al. (1998) Neonatal cord blood leptin: its relationship to birth weight, body mass index, maternal diabetes and steroids. Pediatr Res 43: $338-343$

14. Mise H, Sagawa N, Matsumoto T et al. (1998) Augmented placental production of leptin in preeclampsia: possible involvement of placental hypoxia. J Clin Endocrinol Metab 83: $3225-3229$

15. Zanjani ED, Ascensao JL (1989) Erythropoietin. Transfusion 29: 46-57

16. Widness JA, Teramo KA, Clemons GK et al. (1986) Temporal response of immunoreactive erythropoietin to acute hypoxemia in fetal sheep. Pediatr Res 20: 15-19

17. Conrad KP, Benyo DF, Westerhausen-Larsen A, Miles TM (1996) Expression of erythropoietin by the human placenta. FASEB J 10: 760-766

18. Teramo KA, Widness JA, Clemons GK, Voutilainen PE, McKinlay S, Schwartz R (1987) Amniotic fluid erythropoietin correlates with umbilical plasma erythropoietin in normal and abnormal pregnancy. Obstet Gynecol 69: 710-716

19. Widness JA, Susa JB, Garcia JF et al. (1981) Increased erythropoiesis and elevated erythropoietin in infants born to diabetic mothers and in hyperinsulinemic rhesus fetuses. J Clin Invest 67: 637-642

20. Buescher U, Hertwig K, Wolf C, Dudenhausen JW (1998) Erythropoietin in amniotic fluid as a marker of chronic fetal hypoxia. Int J Gynaecol Obstet 60: 257-263

21. Ma Z, Gingerich RL, Santiago JV, Klein S, Smith CH, Landt M (1996) Radioimmunoassay of leptin in human plasma. Clin Chem 42: 942-946

22. Garcia JF, Ebbe SN, Hollander L, Cutting HO, Miller ME, Cronkite EP (1982) Radioimmunoassay of erythropoietin: circulating levels in normal and polycythemic human beings. J Lab Clin Med 99: 624-635 
23. Widness JA, Teramo KA, Clemons GK et al. (1990) Direct relationship of antepartum glucose control and fetal erythropoietin in human Type I (insulin-dependent) diabetic pregnancy. Diabetologia 33: 378-383

24. Moya FR, Grannum PA, Widness JA, Clemons GK, Copel JA, Hobbins JC (1993) Erythropoietin in human fetuses with immune hemolytic anemia and hydrops fetalis. Obstet Gynecol 82: 353-358

25. Perrine SP, Greene MF, Faller DV (1985) Delay in the fetal globin switch in infants of diabetic mothers. N Engl J Med 312: 334-338

26. Brown MS, Garcia JF, Phibbs RH, Dallman PR (1984) Decreased response of plasma immunoreactive erythropoietin to 'available oxygen' in anemia of prematurity. J Pediatr 105: 793-798

27. Widness Ja, Clemons GK, Garcia JF, Oh W, Schwartz R (1984) Increased immunoreactive erythropoietin in cord serum after labor. Am J Obstet Gynecol 15: 194-197

28. Umemoto Y, Tsuji K, Yang FC et al. (1997) Leptin stimulates the proliferation of murine myelocytic and primitive hematopoietic progenitor cells. Blood 90: 3438-3443
29. Baumann H, Morella KK, White DW et al. (1996) The fulllength leptin receptor has signaling capabilities of interleukin 6-type cytokine receptors. Proc Natl Acad Sci USA 93: 8374-8378

30. Bornstein SR, Licinio J, Tauchnitz R et al. (1998) Plasma leptin levels are increased in survivors of acute sepsis: associated loss of diurnal rhythm in cortisol and leptin secretion. J Clin Endocrinol Metab 83: 280-283

31. Saladin R, De Vos P, Guerre-Millo M et al. (1995) Transient increase in obese gene expression after food intake or insulin admistration. Nature 377: 527-529

32. Mueller WM, Gregoire FM, Stanhope KI et al. (1998) Evidence that glucose metabolism regulates leptin secretion from cultured rat adipocytes. Endocrinology 139: 551-558

33. Lepercq J, Cauzac M, Lahlou N et al. (1998) Overexpression of placental leptin in diabetic pregnancy: a critical role for insulin. Diabetes 47: 847-850

34. Masuzaki H, Ogawa Y, Sagawa N et al. (1997) Nonadipose tissue production of leptin: leptin as a novel placenta-derived hormone in humans. Nat Med 9: 1029-1033 